\title{
Pengaruh Pemangkasan Akar dan Waktu Aklimatisasi Terhadap Pertumbuhan Bibit Tanaman Kemiri (Aleurites moluccana, Willd) Asal Stum
}

\author{
Krisantus Tri Pambudi Raharjo a, Julius Nubatonis ${ }^{\mathrm{b}}$, Eduardus Yosef Neonbeni ${ }^{\mathrm{c}}$ \\ ${ }^{a}$ Fakultas Pertanian, Universitas Timor, Kefamenanu, TTU - NTT, 85613, Indonesia. \\ ${ }^{b}$ Fakultas Pertanian, Universitas Timor, Kefamenanu, TTU - NTT, 85613, Indonesia. \\ Fakultas Pertanian, Universitas Timor, Kefamenanu, TTU - NTT, 85613, Indonesia.
}

\section{Article Info}

\section{Article history:}

Received 10 Agustus 2016

Received in revised form 17 September 2016 Accepted 22 Januari 2017

Keywords:

Aklimatisasi

Kemiri

Pemangkasan Akar

Stump

\section{Abstrak}

Penggunaan anakan yang tumbuh liar sebagai bibit (stump) umum dilakukan pada tanaman kemiri oleh masyarakat di pulau Timor. Penelitian ini bertujuan untuk mengetahui Pengaruh Pemangkasan akar dan Waktu Aklimatisasi terhadap pertumbuhan bibit tanaman kemiri Aleurites maluccana, Willd) asal stum dengan menggunakan Rancangan petak terbagi (Split Plot Design) faktorial 3x3 dengan 3 ulangan. Petak utama perlakuan adalah waktu aklimatisasi, dengan 3 aras yaitu, diaklimatisasi selama 3 minggu (C3), 4 minggu (C4), dan 5 minggu (C5). Anak petak perlakuan adalah pemangkasan akar yang terdiri dari 3 aras yaitu, pemotongan dengan menyisakan panjang akar $15 \mathrm{~cm}(\mathrm{P} 0), 10 \mathrm{~cm}(\mathrm{P} 1)$, dan $5 \mathrm{~cm}\left(\mathrm{P}_{2}\right)$. Hasil penelitian menunjukkan; tidak terjadi interaksi antar perlakuan sisa pangkasan akar dengan waktu aklimatisasi. Pengaruh utama perlakuan sisa pangkasan akar $5 \mathrm{~cm}$ menghasilkan persentase peningkatan bobot kering tanaman $(99,7 \%)$ dan pertumbuhan terbaik. Pengaruh utama perlakuan waktu aklimatisasi 5 minggu menghasilkan persentase peningkatan bobot kering tanaman terbaik $(95,27 \%)$ dan pertumbuhan terbaik.@2017dipublikasikan oleh Savana Cendana.

\section{Pendahuluan}

Tanaman kemiri merupakan salah satu pohon yang dibudidayakan secara luas di dunia dan merupakan jenis asli Indo-Malaysia serta sudah diintroduksikan ke Kepulauan Pasifik sejak jaman dahulu. Di Indonesia, kemiri ditanam untuk tujuan komersial maupun subsistem untuk menunjang kehidupan masyarakat sehari-hari (Krisnawati, et al. 2011).

Masyarakat di pulau Timor biasanya tidak melakukan penyimpanan benih kemiri untuk bahan perbanyakannya, tetapi menanam langsung buah kemiri yang jatuh atau menggunakan anakan yang tumbuh di bawah pohon sebagai bibit cabutan (stump). Namun penanaman dengan kebiasaan ini tingkat keberhasilannya rendah sehingga tidak dapat memenuhi bila dalam jumlah yang besar. Masalah utama adalah, musim jatuhnya buah (masa panen) kemiri untuk wilayah P. Timor yaitu pada bulan November-Desember yang bersamaan dengan musim hujan, dan musim penanamannya. Biji yang jatuh biasanya langsung tumbuh dan menjadi anakan liar. Anakan yang berasal dari biji yang tumbuh pada awal musim hujan (Desember) bila digunakan sebagai bibit pada penanaman bulan Januari-Februari belum cukup berkayu dan kurang bertahan untuk kelangsungan hidupnya, terlebih bila kondisi curah hujannya kurang. Pencabutan juga mudah merusak akar tanaman yang masih muda. Sejauh in belum diketahui pengaruh terputusnya sebagian akar pada cara tanam yang demikian.

Mencabut anakan alami yang cukup berkayu di akhir musim kemarau (telah berumur $8-9$ bulan) dan menyiapkannya menjadi bibit sesuai kriteria dengan cara mengadaptasikannya dalam pembibitan selama beberapa waktu adalah upaya yang dapat ditempuh, sehingga daya tumbuhnya tinggi setelah ditanam di lapangan. Terputusnya akar saat mencabut, dan pemangkasan aka saat menyiapkan tanaman untuk pembibitan dapat mempengaruhi pertumbuhan bibit. Belum ada laporan tentang pengaruh pemangkasan akar terhadap anakan alami (stump) kemiri. Namun Miller dan Neely (1993) melaporkan bahwa memangkas akar secara alami akan merangsang pertumbuhan baru pada ujung potongan. Permasalahannya adalah seberapa banyak bagian akar yang perlu dipotong dan selanjutnya seberapa lama stum tersebut membutuhkan waktu aklimatisasi yang menghasilkan daya tumbuh bibit paling optimal.

Regenerasi akar dalam menanggapi pemangkasan akar terjadi tepat di belakang potongan (Wilcox, H. 1955; Carlson, 1974). Namun, sebagian dari regenerasi akar dapat berasal dari minimal 4 inci $(10 \mathrm{~cm})$ di belakang potongan, tergantung pada spesies (Gilman dan Yeager, 1988). Pemangkasan akar, mengurangi pertumbuhan tunas, merangsang pertumbuhan akar baru sebaga upaya tanaman untuk mengembalikan rasio tajuk_akar seperti sebelum pemangkasan (Maggs, 1964; Richards dan Rowe, 1977; Randolph dan Wiest 1981).

Waktu yang dibutuhkan untuk mengembalikan rasio tajuk/akar tanaman pada pemangkasan akar sangat bervariasi antar spesies. Dua puluh lima har telah dilaporkan untuk bibit persik (Richards dan Rowe, 1977); lima puluh dua hari untuk apel (Schupp dan Ferree, 1990). Pengaruh faktor lingkungan dan fisiologis pada regenerasi akar; tingkat pemangkasan dan waktu pemangkasan akar juga berkontribusi terhadap variasi ini.

Setelah pemangkasan akar ada regenerasi yang cepat dari pertumbuhan akar, yang diperkirakan akan disertai dengan pemulihan serapan air. Richards dan Rowe (1977) melaporkan bahwa serapan air pulih 10 hari setelah pemangkasan akar pada tanaman persik, dan ini terkait erat pemulihan sistem akar.

Dalam menyiapkan bibit stump, proses aklimatisasi merupakan salah satu tahapan yang harus dilaksanakan. Manfaat aklimatisasi bagi bibit stump adalah untuk mengurangi laju respirasi selama bibit dalam masa kritis, yaitu mengalami pemangkasan akar, batang dan daun. Hal ini dimaksudkan untuk meningkatkan persentasi hidup dari bibit stump tersebut. Menurut Pudjiono (2004), aklimatisasi adalah aklimatisasi suatu organisme khususnya tanaman terhadap lingkungan baru, sehingga tanaman dapat beraklimatisasi pada lingkungan kurang optimum di dalam ruangan.
Pudjiono (2004), juga menyatakan bahwa pada tanaman Dieffenbachia yang tidak diaklimatisasi ketika ditempatkan dalam ruang, hasil fotosintesisnya menurun, sehingga pertumbuhan tanaman menjadi terhambat. Dengan aklimatisasi, akan meningkatkan pertumbuhan lebih lanjut setelah ditempatkan di dalam ruangan. aklimatisasi dilakukan untuk menurunkan titik kompensasi cahaya tanaman, sehingga diharapkan dapat menurunkan laju respirasinya. Dalam aklimatisasi yang perlu diperhatikan adalah penurunan intensitas cahaya dan lama penempatan dalam kondisi aklimatisasi adalah

a Pengaruh intensitas cahaya

Intensitas cahaya mempengaruhi secara langsung proses fotosintesis dan respirasi tanaman. Harjadi (1996), melaporkan bahwa tanaman hias daun yang tumbuh di bawah lingkungan cahaya tinggi akan berbeda anatomi dan morfologi dengan tanaman ternaungi. Perbedaan termasuk bentuk dan ukuran daun menjadi lebih tipis dan lebar, ruas daun memanjang dan batang melengkung. Lebih lanjut Harjadi (1996), menyatakan cahaya dibutuhkan dalam pembentukan pigmen antosianin. Keadaan cahaya yang cerah mengakibatkan pengubahan pati ke gula, yang selanjutnya menjadi tersedia untuk sintesis pigmen merah yaitu antosianin. Kondisi ini menjelaskan perubahan warna daun, seperti pada daun tanaman Codiaeum variegatum pictum. Hasil penelitian Airani (1996) menunjukan aklimatisasi tanaman palem Chamaedorea elegans dengan taraf intensitas $75 \%$ lebih baik daripada taraf intensitas $50 \%$. Hal tersebut dapat diketahui dari perbedaan rata-rata jumlah daun yang lebih banyak dan kualitas daunnya yang lebih baik.

b Pengaruh Periode Aklimatisasi

Periode aklimatisasi tergantung jenis tanamannya. Menurut Krisantini (1988), periode aklimatisasi yang tepat diperlukan agar tingkat kompensas cahaya tanaman menurun dan secara fisik tanaman berubah ke arah yang lebih toleran terhadap cahaya gelap. Periode aklimatisasi mempengaruhi pembentukan daun yang semula diproduksi dalam keadaan terang (tebal dan kecil) berubah atau digantikan dengan daun-daun yang lebih tipis. Dengan demikian pada tanaman yang semakin besar dibutuhkan waktu yang semakin lama aklimatisasinya. Hasil penelitian Giantini (2002) menyatakan lama aklimatisasi tergantung jenis tanamannya. Philodendron dan Aglaonema membutuhkan waktu 3 minggu. Tanaman pencinta cahaya Ficus benjamina dan Brassaia aklimatisasi pada naungan $40-80 \%$ selama 5 minggu, Ficus nitida sepuluh minggu pada naungan $50 \%$.

Menurut Sudrajat, et al., (2010), aklimatisasi bertujuan untuk mempersiapkan bibit agar dapat beraklimatisasi pada kondisi lapangan penanaman. Aklimatisasi dilakukan dengan cara meningkatkan cahaya yang diterima oleh bibit, peningkatan jarak antar bibit dan mengurangi penyiraman (hardening off). Pada saat hardening off, bibit masih berada di bawah naungan namun intensitas cahaya ditingkatkan dengan membuka sebagian shadingnet sehingga cahaya yang diterima bibit meningkat. Dalam kondisi demikian, bibit mengalami proses pengayuan (lignifikasi) sehingga lebih kuat. Untuk jenisjenis toleran yang pertumbuhannya lebih baik bila berada di bawah naungan, bibit yang dipindahkan langsung ke areal persemaian terbuka kemungkinan pertumbuhannya kurang optimal, dengan demikian naungan ringan masih diperlukan. aklimatisasi bibit dilakukan secara bertahap dengan mengurangi naungan dan frekuensi penyiraman. aklimatisasi dilakukan paling tidak 2 - 4 minggu sebelum waktu tanam.

\section{Metode}

Penelitian ini dilaksanakan pada tanggal 4 April 2016 sampai 4 Juni 2016, di Persemaian Kebun Bibit Dinas Kehutanan, Desa Dirma Kecamatan Malaka Timur, Kabupaten Malaka dengan menggunakan Rancangan petak terbagi (Split Plot Design) 3x3 faktorial dengan 3 ulangan. Petak utama perlakuan adalah waktu Aklimatisasi, dengan 3 aras yakni, $\mathrm{C}_{1}$ : tahap Aklimatisasi 3 minggu, $\mathrm{C}_{2}$ : di Aklimatisasi selama 4 minggu, dan $\mathrm{C}_{3}$ : selama 5 minggu. Anak petak perlakuan adalah pemangkasan akar yang terdiri dari 3 aras yaitu, $\mathrm{P}_{0}$ : 
menyisakan panjang potongan $15 \mathrm{~cm}, \mathrm{P}_{1}$ : menyisakan panjang potongan $10 \mathrm{~cm}$, dan $\mathrm{P}_{2}$ : menyisakan panjang potongan $5 \mathrm{~cm}$.

Media tanam yang digunakan adalah campuran tanah dan pupuk kandang sapi. Bibit berasal dari tanaman induk yang berumur telah \pm 20 tahun pada kebun milik petani pada minggu pertama dan minggu kedua bulan Februari 2016 di dusun Motasorun Desa Dirma Kecamatan Malaka Timur Kabupaten Malaka. Bibit (stum) tanaman disiapkan sebanyak 45 tanaman selanjutnya diterapkan perlakuan dan dibudidayakan dalam polybag.

Bahan stum dipilih yang berdaun 5 - 7 helai daun selanjutnya memangkas semua daun hingga dekat pangkal tangkainya dan membersihkan tanah yang menempel pada akar dengan cara disiram. Memangkas bagian akar menggunakan pisau tajam yang telah disterilkan. Perlakuan pemangkasan akar yaitu memangkas hingga pangkalnya semua akar lateral dan menyisakan panjang pangkasan akar tunggang (akar primer) sepanjang $15 \mathrm{~cm}(\mathrm{P} 0), 10 \mathrm{~cm}$ (P1) dan $5 \mathrm{~cm}(\mathrm{P} 2)$ dari pangkal akar, setiap perlakuan sebanyak 15 tanaman sehingga seluruhnya terdapat 45 tanaman. Menanam stum ke polybag dengan cara menugal sedalam $+20 \mathrm{~cm}$ selanjutnya memasukan stum dan memadatkan media di sekitar pangkal batang. Penataan polybag ke dalam persemaian (paranet)

Aklimatisasi dilakukan dengan cara meningkatkan cahaya yang diterima oleh bibit dengan cara membuka shading net sehingga cahaya yang diterima bibit meningkat 1 minggu sebelum berakhirnya perlakuan waktu Aklimatisasi.

Analisa data dilakukan dengan menggunakan sidik ragam (Anova) Rancangan Acak Lengkap-Faktorial (RAL-Faktorial) Rata-rata perlakuan selanjutnya diuji dengan menggunakan Duncan Multiple Range Test (DMRT) dengan tingkat signifikan 5\% (Adji, 2000).

\section{Hasil Dan Pembahasan}

Lingkungan Penelitian di dalam paranet memiliki rerata kelembapan udara pada siang hari lebih rendah daripada pagi dan malam hari (Gambar 1.), demikian juga suhu udara siang hari yang lebih rendah daripada pagi dan malam hari.

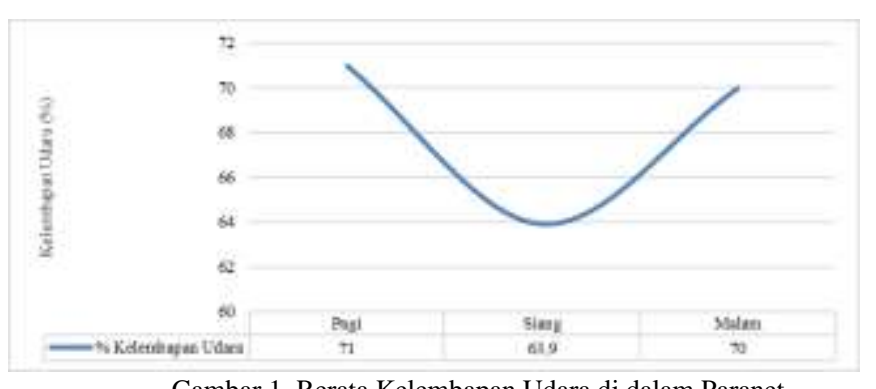

Gambar 1. Rerata Kelembapan Udara di dalam Paranet

Hasil penelitian menunjukkan persentase stump hidup $83 \%$ dari semua petak perlakuan. Stump yang mati terjadi terutama pada stump yang saat penanamannya masih memiliki daun lembaga atau jaringan pada bagian pucuknya masih lunak (belum cukup berkayu).

\subsection{Tinggi Tanaman Awal}

Hasil sidik ragam (Anova) menunjukkan terdapat beda nyata antar nilai rerata tinggi tanaman awal. Tanaman yang berada pada perlakuan waktu aklimatisasi 4 minggu lebih tinggi dibanding pada perlakuan waktu aklimatisasi 5 minggu dan 3 minggu. Tanaman dengan sisa pangkasan akar $15 \mathrm{~cm}$ lebih tinggi dibanding pada sisa pangkasan akar $10 \mathrm{~cm}$ dan $5 \mathrm{~cm}$.

Tabel 1. Tinggi tanaman awal $(\mathrm{cm})$

\begin{tabular}{ccccc}
\hline Sisa & \multicolumn{3}{c}{ Waktu Aklimatisasi (minggu) } & \multirow{2}{*}{ Rerata } \\
\cline { 2 - 4 } Potongan Akar & 3 & 4 & 5 & \\
\hline $15 \mathrm{~cm}$ & 52.33 & 64.33 & 61.33 & $59.33 \mathrm{a}$ \\
$10 \mathrm{~cm}$ & 49.67 & 56.33 & 41.33 & $49.11 \mathrm{~b}$ \\
$5 \mathrm{~cm}$ & 57.67 & 57.67 & 47.33 & $54.22 \mathrm{ab}$ \\
\hline Rerata & $53.22 \mathrm{ab}$ & $59.44 \mathrm{a}$ & $50.00 \mathrm{~b}$ & $(-)$ \\
\hline
\end{tabular}

Keterangan : Angka pada baris dan kolom diikuti huruf sama tidak berbeda pada taraf nyata $(\alpha) 5 \%$ menurut uji DMRT. (-) : Tidak terjadi interaksi antar faktor.

\subsection{Bobot Segar Tanaman Awal}

Hasil analisa menunjukkan terdapat beda nyata antar nilai rerata bobot segar tanaman awal. Bobot segar tanaman yang berada pada perlakuan waktu aklimatisasi 4 minggu lebih berat dibanding pada perlakuan waktu aklimatisasi 5 minggu dan 3 minggu. Bobot segar tanaman dengan sisa pangkasan akar 15 $\mathrm{cm}$ lebih berat dibanding pada sisa pangkasan akar $10 \mathrm{~cm}$ dan $5 \mathrm{~cm}$.

Tabel 2. Bobot segar tanaman awal (g)

\begin{tabular}{lcccc}
\hline Sisa Potongan & \multicolumn{2}{c}{ Waktu Aklimatisasi (minggu) } & \multirow{2}{*}{ Rerata } \\
\cline { 2 - 4 } Akar $(\mathrm{cm})$ & 3 & 4 & 5 & \\
\hline $15 \mathrm{~cm}$ & 19.40 & 30.43 & 30.67 & $26.83 \mathrm{a}$ \\
$10 \mathrm{~cm}$ & 17.30 & 19.80 & 16.37 & $17.82 \mathrm{~b}$ \\
$5 \mathrm{~cm}$ & 20.60 & 22.90 & 18.20 & $20.57 \mathrm{~b}$ \\
\hline Rerata & $19.10 \mathrm{~b}$ & $24.38 \mathrm{a}$ & $21.74 \mathrm{ab}$ & $(-)$ \\
\hline
\end{tabular}

Keterangan : Angka pada baris dan kolom diikuti huruf sama tidak berbeda pada tara nyata $(\alpha) 5 \%$ menurut uji DMRT. (-) : Tidak terjadi interaksi antar faktor.

\subsection{Bobot Kering Tanaman Awal}

Hasil analisa menunjukkan terdapat beda nyata antar nilai rerata bobot kering tanaman awal. Bobot kering tanaman yang berada pada perlakuan waktu aklimatisasi 4 minggu lebih berat dibanding pada perlakuan waktu aklimatisasi 5 minggu dan 3 minggu. Bobot kering tanaman dengan sisa pangkasan akar 15 $\mathrm{cm}$ lebih berat dibanding pada sisa pangkasan akar $10 \mathrm{~cm}$ dan $5 \mathrm{~cm}$.

Tabel 3. Bobot kering tanaman awal (g)

\begin{tabular}{|c|c|c|c|c|}
\hline \multirow{2}{*}{$\begin{array}{l}\text { Sisa Potongan } \\
\text { Akar }(\mathrm{cm})\end{array}$} & \multicolumn{3}{|c|}{ Waktu Aklimatisasi (minggu) } & \multirow{2}{*}{ Rerata } \\
\hline & 3 & 4 & 5 & \\
\hline $15 \mathrm{~cm}$ & 2.91 & 4.57 & 4.60 & $4.03 \mathrm{a}$ \\
\hline $10 \mathrm{~cm}$ & 2.60 & 2.97 & 2.46 & $2.67 \mathrm{~b}$ \\
\hline $5 \mathrm{~cm}$ & 3.09 & 3.44 & 2.73 & $3.09 \mathrm{~b}$ \\
\hline Rerata & $2.87 \mathrm{~b}$ & $3.66 \mathrm{a}$ & $3.26 \mathrm{ab}$ & $(-)$ \\
\hline
\end{tabular}

\subsection{Tinggi Tanaman}

Hasil sidik ragam (Anova) menunjukkan tidak terjadi pengaruh interaksi antara pemangkasan akar dan waktu aklimatisasi pada tinggi bibit tanaman kemiri. Pengaruh utama perlakuan sisa pangkasan akar $5 \mathrm{~cm}$ tinggi tanamannya tidak berbeda dibandingkan dengan sisa pangkasan akar $15 \mathrm{~cm}$, tetapi berbeda nyata dibanding sisa pangkasan akar $10 \mathrm{~cm}$. Tanaman dengan waktu aklimatisasi 4 minggu lebih tinggi dibandingkan dengan waktu aklimatisasi 5 minggu dan 3 minggu.

Tabel 4. Tinggi tanaman $(\mathrm{cm})$

\begin{tabular}{ccrrrr}
\hline Waktu & Sisa Potongan & \multicolumn{3}{c}{ Waktu } & \multicolumn{2}{c}{ Aklimatisasi (minggu) } & \multirow{2}{*}{ Rerata } \\
\cline { 3 - 5 } Pengamatan & Akar & 3 & 4 & 5 & \\
\hline \multirow{3}{*}{$10 \mathrm{MST}$} & $15 \mathrm{~cm}$ & 54.33 & 68.17 & 67.67 & $63.39 \mathrm{a}$ \\
& $10 \mathrm{~cm}$ & 52.00 & 62.00 & 49.00 & $54.33 \mathrm{~b}$ \\
& $5 \mathrm{~cm}$ & 62.00 & 68.00 & 54.00 & $61.33 \mathrm{a}$ \\
\cline { 2 - 5 } & Rerata & $56.11 \mathrm{~b}$ & $66.06 \mathrm{a}$ & $56.89 \mathrm{~b}$ & $(-)$ \\
\hline
\end{tabular}

Keterangan : Angka pada baris dan kolom diikuti huruf sama tidak berbeda pada tara nyata $(\alpha) 5 \%$ menurut uji DMRT. (-) : Tidak terjadi interaksi antar faktor.

\subsection{Luas Daun}

Hasil sidik ragam (Anova) menunjukkan tidak terjadi interaksi antara panjang sisa pangkasan akar dan waktu aklimatisasi pada pengamatan luas daun. Pengaruh utama perlakuan sisa pangkasan akar $5 \mathrm{~cm}$ menghasilkan daun terluas $(360,74 \mathrm{~cm} 2)$ walaupun tidak berbeda nyata dibanding tanaman dengan sisa pangkasan akar $15 \mathrm{~cm}$, dan sisa pangkasan akar $10 \mathrm{~cm}$. Tanaman dengan waktu aklimatisasi 5 minggu menghasilkan daun lebih luas dibandingkan dengan waktu aklimatisasi 4 minggu dan 3 minggu.

\begin{tabular}{|c|c|c|c|c|c|}
\hline \multirow{2}{*}{$\begin{array}{c}\text { Waktu } \\
\text { Pengamatan }\end{array}$} & \multirow{2}{*}{$\begin{array}{c}\text { Sisa Potongan } \\
\text { Akar } \\
\end{array}$} & \multicolumn{3}{|c|}{ Waktu Aklimatisasi (minggu) } & \multirow{2}{*}{ Rerata } \\
\hline & & 3 & 4 & 5 & \\
\hline \multirow{4}{*}{$10 \mathrm{MST}$} & $15 \mathrm{~cm}$ & 268.84 & 163.64 & 334.19 & $255.55 \mathrm{a}$ \\
\hline & $10 \mathrm{~cm}$ & 319.84 & 200.18 & 378.13 & $299.39 a$ \\
\hline & $5 \mathrm{~cm}$ & 337.80 & 330.32 & 414.11 & $360.74 \mathrm{a}$ \\
\hline & Rerata & $308.83 \mathrm{ab}$ & $231.38 b$ & $375.48 \mathrm{a}$ & $(-)$ \\
\hline
\end{tabular}

Keterangan : Angka pada baris dan kolom diikuti huruf sama tidak berbeda pada taraf nyata $(\alpha) 5 \%$ menurut uji DMRT. (-) : Tidak terjadi interaksi antar faktor.

\subsection{Bobot Segar Tanaman}

Hasil sidik ragam (Anova) menunjukkan tidak terjadi interaksi antara panjang sisa pangkasan akar dan waktu aklimatisasi pada pengamatan bobot segar bibit tanaman kemiri. Pengaruh utama perlakuan sisa pangkasan akar 5 $\mathrm{cm}$ menghasilkan bobot segar tanaman terberat (36,2 g) walaupun tidak berbeda nyata dibanding tanaman dengan sisa pangkasan akar $15 \mathrm{~cm}$, dan sisa pangkasan akar $10 \mathrm{~cm}$. Tanaman dengan waktu aklimatisasi 4 minggu menghasilkan bobot segar tanaman terberat $(35,09 \mathrm{~g})$ walaupun tidak berbeda nyata dibanding tanaman dengan waktu aklimatisasi 5 minggu dan 3 minggu.

\begin{tabular}{|c|c|c|c|c|c|}
\hline \multirow{2}{*}{$\begin{array}{c}\text { Waktu } \\
\text { Pengamatan }\end{array}$} & \multirow{2}{*}{$\begin{array}{c}\text { Sisa Potongan } \\
\text { Akar }\end{array}$} & \multicolumn{3}{|c|}{ Waktu Aklimatisasi (minggu) } & \multirow{2}{*}{ Rerata } \\
\hline & & 3 & 4 & 5 & \\
\hline \multirow{4}{*}{$10 \mathrm{MST}$} & $15 \mathrm{~cm}$ & 24.30 & 31.43 & 33.10 & $29.61 \mathrm{a}$ \\
\hline & $10 \mathrm{~cm}$ & 23.73 & 30.07 & 26.73 & $26.84 \mathrm{a}$ \\
\hline & $5 \mathrm{~cm}$ & 27.73 & 43.77 & 37.10 & $36.20 \mathrm{a}$ \\
\hline & Rerata & $25.26 \mathrm{a}$ & $35.09 \mathrm{a}$ & $32.31 \mathrm{a}$ & $(-)$ \\
\hline
\end{tabular}

Keterangan : Angka pada baris dan kolom diikuti huruf sama tidak berbeda pada taraf nyata $(\alpha) 5 \%$ menurut uji DMRT. (-) : Tidak terjadi interaksi antar faktor

\subsection{Bobot Segar Akar}

Hasil sidik ragam (Anova) menunjukkan tidak terjadi interaksi antara panjang sisa pangkasan akar dan waktu aklimatisasi pada pengamatan bobot segar akar bibit tanaman kemiri. Pengaruh utama perlakuan sisa pangkasan akar $5 \mathrm{~cm}$ menghasilkan bobot segar tanaman terberat $(5,29 \mathrm{~g})$ berbeda nyata dibanding tanaman dengan sisa pangkasan akar $15 \mathrm{~cm}$, dan sisa pangkasan akar $10 \mathrm{~cm}$. Tanaman dengan waktu aklimatisasi 5 minggu menghasilkan bobot 
segar akar terberat $(4,97 \mathrm{~g})$ walaupun tidak berbeda nyata dibanding tanaman dengan waktu aklimatisasi 4 minggu dan 3 minggu.

Tabel 7. Bobot segar akar $(\mathrm{g})$

\begin{tabular}{cccccc}
\hline Waktu & Sisa Potongan & \multicolumn{3}{c}{ Waktu Aklimatisasi (minggu) } & \multirow{2}{*}{ Rerata } \\
\cline { 3 - 5 } Pengamatan & Akar & 3 & 4 & 5 & \\
\hline \multirow{3}{*}{$10 \mathrm{MST}$} & $15 \mathrm{~cm}$ & 1.90 & 2.50 & 3.73 & $2.71 \mathrm{~b}$ \\
& $10 \mathrm{~cm}$ & 4.40 & 3.76 & 5.27 & $4.48 \mathrm{ab}$ \\
& $5 \mathrm{~cm}$ & 3.57 & 6.39 & 5.90 & $5.29 \mathrm{a}$ \\
\cline { 2 - 5 } & Rerata & $3.29 \mathrm{a}$ & $4.22 \mathrm{a}$ & $4.97 \mathrm{a}$ & $(-)$ \\
\hline Knnnnnn
\end{tabular}

Keterangan : Angka pada baris dan kolom diikuti huruf sama tidak berbeda pada tara nyata $(\alpha) 5 \%$ menurut uji DMRT. $(-)$ : Tidak terjadi interaksi antar faktor.

\subsection{Panjang Akar}

Hasil sidik ragam (Anova) menunjukkan tidak terjadi interaksi antara panjang sisa pangkasan akar dan waktu aklimatisasi pada pengamatan panjang akar tanaman (setelah bibit dipanen). Pengaruh utama perlakuan sisa pangkasan akar $5 \mathrm{~cm}$ menghasilkan akar terpanjang $(364 \mathrm{~cm})$ walaupun tidak berbeda nyata dibanding tanaman dengan sisa pangkasan akar $15 \mathrm{~cm}$, dan sisa pangkasan akar $10 \mathrm{~cm}$. Tanaman dengan waktu aklimatisasi 5 minggu menghasilkan akar terpanjang $(331,67 \mathrm{~cm})$ walaupun tidak berbeda nyata dibanding tanaman dengan waktu aklimatisasi 4 minggu dan 3 minggu.

Tabel. 8. Panjang akar $(\mathrm{cm})$

\begin{tabular}{cccccc}
\hline Waktu & Sisa Potongan & \multicolumn{3}{c}{ Waktu Aklimatisasi (minggu) } & \multirow{2}{*}{ Rerata } \\
\cline { 3 - 5 } Pengamatan & Akar & 3 & 4 & 5 & \\
\hline \multirow{3}{*}{$10 \mathrm{MST}$} & $15 \mathrm{~cm}$ & 199.33 & 239.67 & 324.00 & $254.33 \mathrm{a}$ \\
& $10 \mathrm{~cm}$ & 325.33 & 220.33 & 303.00 & $282.89 \mathrm{a}$ \\
& $5 \mathrm{~cm}$ & 325.67 & 398.33 & 368.00 & $364.00 \mathrm{a}$ \\
\cline { 2 - 5 } & Rerata & $283.44 \mathrm{a}$ & $286.11 \mathrm{a}$ & $331.67 \mathrm{a}$ & $(-)$ \\
\hline
\end{tabular}

Keterangan : Angka pada baris dan kolom diikuti huruf sama tidak berbeda pada tara nyata $(\alpha) 5 \%$ menurut uji DMRT. (-) : Tidak terjadi interaksi antar faktor.

\subsection{Bobot Kering Tanaman}

Hasil sidik ragam (Anova) menunjukkan tidak terjadi interaksi antara panjang sisa pangkasan akar dan waktu aklimatisasi pada pengamatan bobot kering bibit tanaman kemiri. Pengaruh utama perlakuan sisa pangkasan akar 15 $\mathrm{cm}$ menghasilkan bobot kering tanaman terberat $(6,32 \mathrm{~g})$ tidak berbeda nyata dibanding tanaman dengan sisa pangkasan akar $5 \mathrm{~cm}$, dan tetapi berbeda nyata dibanding tanaman dengan sisa pangkasan akar $10 \mathrm{~cm}$. Tanaman dengan waktu aklimatisasi 4 minggu menghasilkan bobot kering tanaman terberat $(6,40 \mathrm{~g})$ tidak berbeda nyata dibanding tanaman dengan waktu aklimatisasi 5 minggu, tetapi berbeda nyata dibanding tanaman dengan waktu aklimatisasi 3 minggu.

Tabel 9. bobot kering tanaman $(\mathrm{g})$

\begin{tabular}{cccccc}
\hline Waktu & Sisa Potongan & \multicolumn{2}{c}{ Waktu Aklimatisasi (minggu) } & \multirow{2}{*}{ Rerata } \\
\cline { 3 - 5 } Pengamatan & Akar & 3 & 4 & 5 & \\
\hline \multirow{3}{*}{$10 \mathrm{MST}$} & $15 \mathrm{~cm}$ & 4.41 & 7.35 & 7.21 & $6.32 \mathrm{a}$ \\
& $10 \mathrm{~cm}$ & 4.52 & 5.41 & 4.90 & $4.94 \mathrm{~b}$ \\
& $5 \mathrm{~cm}$ & 5.62 & 6.46 & 6.26 & $6.11 \mathrm{a}$ \\
\cline { 2 - 5 } & Rerata & $4.85 \mathrm{~b}$ & $6.40 \mathrm{a}$ & $6.13 \mathrm{a}$ & $(-)$ \\
\hline
\end{tabular}

Keterangan : Angka pada baris dan kolom diikuti huruf sama tidak berbeda pada taraf nyata $(\alpha) 5 \%$ menurut uji DMRT. (-) : Tidak terjadi interaksi antar faktor.

\subsection{Bobot Kering Akar}

Hasil sidik ragam (Anova) menunjukkan tidak terjadi interaksi antara panjang sisa pangkasan akar dan waktu aklimatisasi pada pengamatan bobot segar akar bibit tanaman kemiri. Pengaruh utama perlakuan sisa pangkasan akar $5 \mathrm{~cm}$ menghasilkan bobot kering akar terberat $(0,41 \mathrm{~g})$ berbeda nyata dibanding tanaman dengan sisa pangkasan akar $15 \mathrm{~cm}$, dan sisa pangkasan akar $10 \mathrm{~cm}$. Tanaman dengan waktu aklimatisasi 5 minggu menghasilkan bobot kering akar terberat $(0,36 \mathrm{~g})$ walaupun tidak berbeda nyata dibanding tanaman dengan waktu aklimatisasi 4 minggu dan 3 minggu.

Tabel 10. Bobot kering akar

\begin{tabular}{cccccc}
\hline \multirow{2}{*}{$\begin{array}{c}\text { Waktu } \\
\text { Pengamatan }\end{array}$} & Sisa Potongan & \multicolumn{3}{c}{ Waktu Aklimatisasi (minggu) } & \multirow{2}{*}{ Rerata } \\
\cline { 3 - 5 } & Akar & 3 & 4 & 5 & \\
& $15 \mathrm{~cm}$ & 0.17 & 0.22 & 0.32 & $0.24 \mathrm{~b}$ \\
$10 \mathrm{MST}$ & $10 \mathrm{~cm}$ & 0.33 & 0.22 & 0.34 & $0.30 \mathrm{~b}$ \\
& $5 \mathrm{~cm}$ & 0.46 & 0.33 & 0.43 & $0.41 \mathrm{a}$ \\
\cline { 2 - 5 } & Rerata & $0.32 \mathrm{a}$ & $0.26 \mathrm{a}$ & $0.36 \mathrm{a}$ & $(-)$ \\
\hline
\end{tabular}

Keterangan : Angka pada baris dan kolom diikuti huruf sama tidak berbeda pada taraf nyata $(\alpha) 5 \%$ menurut uji DMRT. (-) : Tidak terjadi interaksi antar faktor.

Pengamatan lebih lanjut menunjukkan bahwa tanaman yang diberi perlakuan sisa pangkasan akar $5 \mathrm{~cm}$ selalu menghasilkan bobot kering akar terberat pada setiap taraf waktu aklimatisasi.

\subsection{Persentase Peningkatan Tinggi Tanaman}

Hasil sidik ragam (Anova) menunjukkan tidak terjadi interaksi antara panjang sisa pangkasan akar dan waktu aklimatisasi pada pengamatan persentase peningkatan tinggi bibit tanaman kemiri. Pengaruh utama perlakuan sisa pangkasan akar $5 \mathrm{~cm}$ menghasilkan persentase peningkatan tinggi tanaman tertinggi $(13,46 \%)$ tidak berbeda nyata dibanding tanaman dengan sisa pangkasan akar $10 \mathrm{~cm}$, dan tetapi berbeda nyata dibanding tanaman dengan sisa pangkasan akar $15 \mathrm{~cm}$. Tanaman dengan waktu aklimatisasi 4 minggu menghasilkan peningkatan tinggi tanaman tertinggi $(14,64 \%)$ tidak berbeda nyata dibanding tanaman dengan waktu aklimatisasi 4 minggu, tetapi berbeda nyata dibanding tanaman dengan waktu aklimatisasi 3 minggu.

$\underline{\text { Tabel 11. Persentase Peningkatan tinggi tanaman (\%) }}$

\begin{tabular}{cccccc}
\hline Waktu & Sisa Potongan & \multicolumn{3}{c}{ Waktu Aklimatisasi (minggu) } & \multirow{2}{*}{ Rerata } \\
\cline { 3 - 5 } Pengamatan & Akar & 3 & 4 & 5 & \\
\hline \multirow{3}{*}{$10 \mathrm{MST}$} & $15 \mathrm{~cm}$ & 3.78 & 6.07 & 11.11 & $6.99 \mathrm{~b}$ \\
& $10 \mathrm{~cm}$ & 4.74 & 10.0 & 18.29 & $11.03 \mathrm{a}$ \\
& $5 \mathrm{~cm}$ & 7.94 & 17.95 & 14.51 & $13.46 \mathrm{a}$ \\
\cline { 2 - 5 } & Rerata & $5.49 \mathrm{~b}$ & $11.36 \mathrm{a}$ & $14.64 \mathrm{a}$ & $(-)$ \\
\hline
\end{tabular}

Keterangan : Angka pada baris dan kolom diikuti huruf sama tidak berbeda pada taraf nyata $(\alpha) 5 \%$ menurut uji DMRT. (-) : Tidak terjadi interaksi antar faktor.

\subsection{Persentase Peningkatan Bobot Kering Tanaman}

Hasil sidik ragam (Anova) menunjukkan tidak terjadi interaksi antara panjang sisa pangkasan akar dan waktu aklimatisasi pada pengamatan luas daun. Pengaruh utama perlakuan sisa pangkasan akar $5 \mathrm{~cm}$ persentase peningkatan bobot kering tanaman tertinggi $(99,70 \%)$ berbeda nyata dibanding tanaman dengan sisa pangkasan akar $15 \mathrm{~cm}$ dan sisa pangkasan akar $10 \mathrm{~cm}$. Tanaman dengan waktu aklimatisasi 5 minggu menghasilkan persentase peningkatan bobot kering tanaman tertinggi $(95,27 \%)$ berbeda nyata dibanding tanaman dengan waktu aklimatisasi 4 minggu dan 3 minggu.

Pengamatan lebih lanjut menunjukkan bahwa semakin pendek sisa pangkasan akar meningkatkan persentase peningkatan bobot kering tanaman, selain itu semakin lama waktu aklimatisasi semakin meningkatkan persentase peningkatan bobot kering tanaman.

Tabel. 12. Persentase peningkatan bobot kering tanaman (\%)

\begin{tabular}{cccccc}
\hline Waktu & Sisa Potongan & \multicolumn{3}{c}{ Waktu Aklimatisasi (minggu) } & \multirow{2}{*}{ Rerata } \\
\cline { 2 - 5 } Pengamatan & Akar & 3 & 4 & 5 & \\
\hline \multirow{3}{*}{$10 \mathrm{MST}$} & $15 \mathrm{~cm}$ & 52.33 & 61.10 & 57.26 & $56.90 \mathrm{c}$ \\
& $10 \mathrm{~cm}$ & 74.08 & 82.55 & 100.04 & $85.56 \mathrm{~b}$ \\
& $5 \mathrm{~cm}$ & 83.34 & 87.26 & 128.50 & $99.70 \mathrm{a}$ \\
\cline { 2 - 5 } & Rerata & $69.92 \mathrm{~b}$ & $76.97 \mathrm{~b}$ & $95.27 \mathrm{a}$ & $(-)$ \\
\hline
\end{tabular}

Keterangan : Angka pada baris dan kolom diikuti huruf sama tidak berbeda pada tara nyata $(\alpha) 5 \%$ menurut uji DMRT. (-) : Tidak terjadi interaksi antar faktor.

\subsection{Nisbah Bobot Kering Tajuk Akar}

Pengamatan nisbah Bobot kering tajuk/akar daun sesuai hasil sidik ragam (Anova) menunjukkan tidak terjadi interaksi antara Panjang sisa pangkasan akar dan waktu aklimatisasi.

Panjang sisa pangkasan akar $15 \mathrm{~cm}$ nisbah Bobot kering batang daun /akar lebih tinggi dibandingkan dengan panjang potongan $10 \mathrm{~cm}$ dan $5 \mathrm{~cm}$ setelah panen, sedangkan waktu aklimatisasi 9 minggu memiliki nisbah Bobot kering batang daun/akar lebih tinggi yaitu 10 minggu lebih tinggi dibandingkan dengan waktu aklimatisasi 10 dan 8 minggu.

Tabel 13. Nisbah Bobot kering Tajuk/akar $\left(\mathrm{cm}^{2} / \mathrm{g}\right)$

\begin{tabular}{|c|c|c|c|c|c|}
\hline \multirow{2}{*}{$\begin{array}{c}\text { Waktu } \\
\text { Pengamatan }\end{array}$} & \multirow{2}{*}{$\begin{array}{c}\text { Sisa Potongan } \\
\text { Akar }\end{array}$} & \multicolumn{3}{|c|}{ Waktu Aklimatisasi (minggu) } & \multirow{2}{*}{ Rerata } \\
\hline & & 3 & 4 & 5 & \\
\hline \multirow{4}{*}{$10 \mathrm{MST}$} & $15 \mathrm{~cm}$ & 29.21 & 36.55 & 23.41 & $29.72 \mathrm{a}$ \\
\hline & $10 \mathrm{~cm}$ & 13.56 & 35.13 & 14.53 & $21.07 \mathrm{a}$ \\
\hline & $5 \mathrm{~cm}$ & 13.67 & 20.45 & 17.35 & $17.16 \mathrm{a}$ \\
\hline & Rerata & $18.81 \mathrm{a}$ & $30.71 \mathrm{a}$ & $18.43 \mathrm{a}$ & $(-)$ \\
\hline
\end{tabular}

Keterangan : Angka pada baris dan kolom diikuti huruf sama tidak berbeda pada taraf nyata $(\alpha) 5 \%$ menurut uji DMRT. (-) : Tidak terjadi interaksi antar faktor.

\subsection{Pembahasan}

Keadaan awal bibit (stump) menunjukkan bahwa tanaman ke dalam perlakuan panjang sisa pangkasan akar memiliki tinggi tanaman, bobot segar, dan bobot kering yang tidak berbeda nyata (estimasi). Selanjutnya pada tanaman yang diberi perlakuan waktu aklimatisasi juga memiliki tinggi tanaman, bobot segar, dan bobot kering yang tidak berbeda nyata (Tabel 1 , Tabel 2, dan Tabel 3.) demikian pula pada kombinasi perlakuannya. Setelah panen menunjukkan bahwa panjang sisa pangkasan akar $5 \mathrm{~cm}$ memberikan hasil pertumbuhan paling baik, meliputi; panjang akar, luas daun, bobot segar akar, bobot kering akar, bobot segar tanaman, persentase peningkatan tinggi tanaman, persentase peningkatan bobot kering tanaman. Perlakuan panjang sisa pangkasan akar $5 \mathrm{~cm}$ juga mengakibatkan pertumbuhan akar baru yang lebih ekstensif ditunjukkan pula dengan menurunnya nisbah (rasio) tajuk/akar. Hasil ini mendukung laporan sebelumnya yang menyatakan bahwa, pemangkasan akar, mengurangi pertumbuhan tunas, merangsang pertumbuhan akar baru sebagai upaya tanaman untuk mengembalikan rasio tajuk_akar seperti sebelum pemangkasan (Maggs, 1964; Richards dan Rowe, 1977; Randolph dan Wiest, 1981). Laporan lainnya juga menyatakan bahwa, pemangkasan akar menginduksi penurunan rasio tajuk_akar (Tanaka, Walsted dan Borrecco, 1976; Bacon dan Bachelard, 1978; Randolph dan Wiest, 1981), dan berhubungan dengan peningkatan kinerja bibit pohon pasca-transplanting (Benson dan Shepherd, 1977). Menurut Kramer dan Kozlowski (1979), masing-masing 
spesies memiliki rasio tajuk/akar yang khas. Ketika rasio berubah, seperti saat transplanting, tanaman merespon dengan mengalihkan asimilat untuk mengganti bagian yang dipangkas.

Waktu aklimatisasi yang paling baik dalam penelitian ini yaitu 5 minggu yang menunjukan hasil pertumbuhan yang paling baik, meliputi: panjang akar, luas daun, bobot segar akar, bobot kering akar, persentase peningkatan tinggi tanaman, persentase peningkatan bobot kering tanaman. Aklimatisasi 5 minggu mengakibatkan pertumbuhan akar baru yang lebih ekstensif ditunjukkan pula dengan menurunnya nisbah (rasio) tajuk/akar.

Aklimatisasi dilakukan dengan cara meningkatkan cahaya yang diterima oleh bibit, peningkatan jarak antar bibit dan mengurangi penyiraman (hardening off). Pada saat hardening off, bibit masih berada di bawah naungan namun intensitas cahaya ditingkatkan dengan membuka sebagian shadingnet sehingga cahaya yang diterima bibit meningkat. Dalam kondisi demikian, bibit mengalami proses pengayuan (lignifikasi) sehingga lebih kuat. Untuk jenisjenis toleran yang pertumbuhannya lebih baik bila berada di bawah naungan, bibit yang dipindahkan langsung ke areal persemaian terbuka kemungkinan pertumbuhannya kurang optimal, dengan demikian naungan ringan masih diperlukan. Aklimatisasi bibit dilakukan secara bertahap dengan mengurangi naungan dan frekuensi penyiraman. aklimatisasi dilakukan paling tidak 2 - 4 minggu sebelum waktu tanam (Sudrajat, et al., 2010).

\section{Simpulan}

Tidak terjadi interaksi antara panjang sisa pangkasan akar dengan waktu aklimatisasi pada semua parameter pengamatan. Pengaruh utama perlakuan sisa pangkasan akar $5 \mathrm{~cm}$ menghasilkan persentase peningkatan bobot kering tanaman terbaik $(99,7 \%)$. Pengaruh utama perlakuan waktu aklimatisasi 5 minggu menghasilkan persentase peningkatan bobot kering tanaman terbaik $(95,27 \%)$. Walaupun tidak terjadi interaksi, kombinasi perlakuan sisa pangkasan akar $5 \mathrm{~cm}$ dengan waktu aklimatisasi 5 minggu menghasilkan persentase peningkatan bobot kering tanaman terbaik $(128,5 \%)$.

\section{Pustaka}

Adji, 2000. Rancangan Percobaan Praktis Bidang Pertanian. Kanisius, Yogyakarta

Airani, R. 1996. Pengaruh Tingkat Naungan dan Dosis Pemupukan Selama Iklimatisasi Terhadap Kualitas dan Daya Hidup Bibit Palem (Chamaedorea elegans) Setelah Simulasi Pengangkutan. Skripsi. Jurusan Budidaya Pertanian, Fakultas Pertanian, Institut Pertanian Bogor. Bogor. Tidak diterbitkan.

Bacon, G. J. and E. P. Bachelard. 1978. The influence of nursery conditioning treatments on some physiologicalresponses of recently transplanted seedlings of Pinus vcaribaea Mor. var. hondurensisB \& G. Aust. For. Res. 8:171-183.

Benson, A. D. and K. R. Shepherd. 1977. Effects of nursery practice on seedling characteristics and field performance: II. Nursery root wrenching. N. Z. J. For. Res. 7(1):68-76.

Carlson, W. C. 1974. Root initiation induced by root pruning in northern red oak. Forest Res. Rev., Ohio Agr. Res. Develop. Center, Wooster, p. 1416.

Giantini, M. N. 2002. Studi Penataan dan Pemeliharaan Indoor Garden (Taman Dalam Ruang) di Kotamadya Bandung. Skripsi. Jurusan Budidaya Pertanian, Fakultas Pertanian, Institut Pertanian Bogor. Bogor. Tidak diterbitkan.

Gilman, E. F. and T. H. Yeager. 1988. Root initiation in rootpruned hardwoods. HortScience. 23 (4):775.

Kramer, P. J. and T. T. Kozlowski. 1979. Physiology of Woody Plants. Academic Press, N.Y.

Krisnawati, H., Kallio, M., Kanninen, M., 2011. Aleurites moluccana (L.) Willd. Ekologi, Silvikultur dan Produktivitas. CIFOR, Bogor, Indonesia.

Krisantini, 1988. Tanaman Hias Daun. Jurusan Budidaya Pertanian. Fakultas Pertanian. Institut Pertanian Bogor. Bogor.

Maggs, D. H. 1964. Growth rates in relation to assimilate supply and demand. I. Leaves and roots as limiting regions. J. Expt. Bot. 15:574-583.

Miller, F. D., and D. Neely. 1993. The effect of trenching on growth and plant health of selected species of shade trees. J. Arboric. 19 (4): 226-229.

Pudjiono S. 2004. Dasar-dasar Umum Cara Pembuatan Stek dari Pohon Hutan. From: http://www. Biotiforda.or.id/Pembiakan Vegetatif Biotiforda. diakses tanggal 5 Januari 2016.

Randolph, W.S. and Wiest, S.C. 1981. Relative importance of tractable factors affecting the establishment of transplanted holly. Journal of the American Society for Horticultural Science 106(2):207-210.

Richards, D. and Rowe, R.N. 1977. Effects of root restriction, root pruning and 6-Benzylaminopurine on the growth of peach seedlings. Annals of Botany 41:729-740.

Schupp, J.R. and Ferree, D.C. 1990. Influence of time of root pruning on growth, mineral nutrition, net photosynthesis and transpiration of young apple trees. Scientia Horticulturae 42:299-306.

Sudrajat, D.J., Kurniaty, R., Syamsuwida, D., Nurhasybi, dan Budiman, B. 2010. Kajian standardisasi mutu bibit tanaman hutan di Indonesia. Seri Teknologi Perbenihan Tanaman Hutan, ISBN 978-979-3539-20-1.
Tanaka, Y., J.D. Walsted and J.E. Borrecco. 1976. The effect of wrenching on morphology and field performance of Douglas fir and loblolly pine seedlings. Can. J. Forest. Res.6:453-458.

Wilcox, H. 1955. Regeneration of injured root systems of noble fir. Bot. Gaz. 116: $221-234$. 